\title{
Brugmansia suaveolens Leaf Productivity and Alkaloid Contents Under Different Doses of Organic Fertilizer
}

\author{
Rafael B. Reis ${ }^{1}$, Felipe S. Bragagnolo ${ }^{1}$, Thiago M. R. Gianeti ${ }^{2}$, Sérgio A. Rodrigues ${ }^{1}$, Cristiano S. Funari ${ }^{1}$, \\ Gabriela G. Gonçalves ${ }^{1}$ \& Lin C. Ming ${ }^{1}$ \\ ${ }^{1}$ Faculdade de Ciências Agronômicas, Universidade Estadual Paulista, Botucatu, SP, Brazil \\ ${ }^{2}$ Laboratório Central, Faculdade de Ciências Agronômicas, Universidade Estadual Paulista, Botucatu, SP, Brazil \\ Correspondence: Rafael B. Reis, Faculdade de Ciências Agronômicas, Universidade Estadual Paulista, Botucatu, \\ SP, Brazil. Tel: 55-143-880-7510. E-mail: rafaelbonchristiano@gmail.com
}

Received: November 22, 2018

Accepted: December 23, 2018

Online Published: February 15, 2019

doi:10.5539/jas.v11n3p341

URL: https://doi.org/10.5539/jas.v11n3p341

\begin{abstract}
According to the World Health Organization, the use of mineral fertilizers and pesticides should be avoided in the cultivation of medicinal plants due to their potential antagonistic actions. Brugmansia spp. is a perennial bush native to South America, but it is also cultivated in Europe, Central America, and Asia due to its ornamental characteristics. Aerial parts of this plant are used in ethnomedicine to alleviate ulcers and pain, as well as to treat abscesses, fungal infection of the skin, and dermatitis. Tropane alkaloids scopolamine and atropine are recognized as active principles of this plant. This study evaluated the applicability of organic agricultural techniques in the cultivation of Brugmansia suaveolens. The influence of different dosages (0-60 tons/ha) of organic fertilizer on the mass productivity of plant shoot as well as their atropine and scopolamine contents were investigated. The average dry matter of leaves $(26.54 \pm 5.12-55.41 \pm 12.85 \mathrm{~g})$ and stems $(26.73 \pm 8.51-58.60 \pm 17.62$ g) per plant increased with increasingly availability of organic fertilizer (0-60 ton/ha). The same behavior was observed when the contents of the active tropane alkaloids scopolamine $(0.72 \pm 0.03-0.86 \pm 0.13 \mathrm{mg} / \mathrm{g})$ and atropine $(0.79 \pm 0.03-0.96 \pm 0.11 \mathrm{mg} / \mathrm{g})$ were monitored by gas chromatography coupled with mass spectrometer. Overall, the treatment at the maximum level tested in this work $(60 \mathrm{ton} / \mathrm{ha})$ should be preferred over the other treatments. B. suaveolens could be a potential source of tropane alkaloids for the community of Botucatu city, which is a leading city in Brazil for the cultivation of food products under organic, biodynamic, and agroecology premises.
\end{abstract}

Keywords: Brugmansia, organic agriculture, scopolamine, atropine, tropane alkaloids

\section{Introduction}

Brugmansia suaveolens (Humb. \& Bonpl. ex Willd) Doce (Solanaceae) is a large perennial bush with woody stems, often heavily branched and can grow as tall as 5 meters. It's very large, usually smooth-margined leaves are oval and pointed at the ends. The flowers, which can grow up to $30 \mathrm{~cm}$, hang down at an angle and are usually pink and/or white. The calyx and corolla each have five points. During the evening and at night, the flowers exude a bewitching and inebriating scent. The fruits, which form only very rarely, are short and spindle-shaped with an irregularly gibbous surface and contain large (approximately $1 \mathrm{~cm}$ ) light brown seeds (Rätsch, 1997).

This specie is native in tropical South America but is also cultivated in Europe, Central America, and Asia, due to its ornamental characteristics (Lorenzi \& Souza, 2008). Schultes and Hofmann (1983) stated more specifically that the B. suaveolens is native to the warmer plains of South-eastern Brazil. Infusions of B. suaveolens leaves are used in ethnomedicine to alleviate ulcers and pain and to threat abscesses, fungal infection of the skin, and dermatitis (Parker et al., 2007; Revilla, 2002). This plant is also used in South America as an entheogen in religious rituals due to the presence of psychoactive tropane alkaloids, mainly scopolamine and atropine (Revilla, 2002). About the chemical constituents, the literature mentions the presence of many tropane alkaloids with higher levels of scopolamine, in B. arborea (Lorenzi et al., 2011).

Both scopolamine and atropine are broadly employed in pharmaceutical formulations as muscarinic antagonists, anticholinergics, antispasmodics, preoperative, and postoperative medications as analgesics, 
sedatives as well as to treat asthma, sialorrhea, Parkinson's disease, and motion sickness (Jakabová et al., 2012). Scopolamine has a higher market demand and price than other tropane alkaloids due to its higher pharmacological activity and lower side effects (Qiang et al., 2016).

The global scopolamine market was valued at US\$ 370.4 million in 2017 (Coherent Market Insights Analysis, 2018). As these tropane alkaloids are difficulty and high costly to synthase, these alkaloids continue to be extracted from several species of Solanaceae, including Hyoscyamuns niger L., Anisodus tanguticus, Scopolia tangutica Maxim, Atropa belladonna, and several Datura species (Cardillo et al., 2010; Qiang et al., 2016). The aerial parts of Datura spp., obtained principally from India, is the main source, containing not less than $0.25 \%$ of alkaloids calculated as hyoscyamine (Evans, 2009). Brugmansia sanguinea has also proved to be an interesting plant with respect to its wide range of tropane alkaloids cultivated commercially in Ecuador, with yields of about $0.8 \%$ scopolamine. Plantations have an economically useful life of about 10 years (Evans, 2009).

According to the World Health Organization (2003), the use of mineral fertilizers and pesticides should be avoided as much as possible in the cultivation of medicinal plants, due to the antagonistic action that traces of these products acquire when interacting with the active ingredient of certain plants and even the products themselves, used in the cultivation, which can harm human and animal health. Thus, the ideal cultivation of medicinal plants will use methods with the least environmental impact. Moreover, synthetic chemicals should be avoided as to not contaminate and compromise the quality of the raw material.

To meet these supranational recommendations, the present work evaluated the applicability of organic agricultural techniques in the cultivation of $B$. suaveolens. The influence of different dosages of organic fertilizer on the mass productivity of the aerial parts of plants as well as on their atropine and scopolamine contents was investigated.

\section{Material Studied and Methods}

\subsection{Plant Material and Seedling Preparation}

The plant material was obtained from cuttings of young shoots of vigorous plants cultivated at the Lageado Experimental Farm, Faculty of Agricultural Sciences, São Paulo State University (FCA/UNESP) in the city of Botucatu, State of São Paulo, Brazil. These plants were identified as Brugmansia suaveolens (Humb. \& Bonpl. ex Willd) Doce and a voucher specimen is deposited in the Botanical Garden of the São Paulo State University (UNESP), under number 33186. The branches of the matrix plant were cut with pruning shears and taken to the medicinal Plant Laboratory at UNESP where leaves were removed from the approximately $20 \mathrm{~cm}$ long cuttings.

After preparation of the cuttings, they were inserted into the substrate. The substrate was prepared in advance in the proportion of 3:2:1, which represents 3 parts of soil for 2 parts of sand and 1 part of compost. However, the texture of the substrate obtained was considerably sandy, so it was changed to a ratio of $1: 1$, i.e. $50 \%$ soil and $50 \%$ compost. The compost was a mixture of three materials: organic matter, coconut fiber, and castor bean pie (very rich in N). The substrate was shoveled into 1 liter plastic sachets which then received the 152 cuttings.

The cuttings inserted into the substrate were transferred to the glass greenhouse of the Horticulture Department and arranged on a countertop and covered with a shade cloth. With the transfer of the greenhouse cuttings to the shade house, in just two weeks the first leaves and branches appeared. The seedlings were watered periodically until they reached $50 \mathrm{~cm}$ in height. They showed healthy green appearance and leaves. When the seedlings were ready, they were transplanted into the experimental area.

\subsection{Soil Preparation Prior Planting}

The experimental crop was developed in the experimental area of the Department of Horticulture of FCA/UNESP in Botucatu, São Paulo State, Brazil. The chemical characteristics of the soil in this experimental area are in Tables 1 and 2.

Initially a tractor was used to plow and remove plants that existed in that location. Then calcium carbonate $(\mathrm{CaO})$ was applied manually, aiming to distribute the lime in the most uniform way possible. Finally, the $\mathrm{CaO}$ was incorporated into the ground with the aid of a rotating hoe.

Table 1. Soil nutrient analysis at the experimental area (Santos, 2016)

\begin{tabular}{|c|c|c|c|c|c|c|c|c|c|c|c|}
\hline Sample (cm) & pH & M.O. & $\mathbf{P}_{\text {resina }}$ & $\mathbf{H}+\mathbf{A l}$ & $\mathbf{K}$ & $\mathrm{Ca}$ & Mg & SB & CTC & V\% & $\mathbf{S}$ \\
\hline & $\mathrm{CaCl}_{2}$ & $\mathrm{~g} / \mathrm{dm}^{3}$ & $\mathrm{mg} / \mathrm{dm}^{3}$ & & --- & $-\cdots$ & $--\mathrm{m}$ & $\mathrm{l}_{\mathrm{c}} / \mathrm{dm}^{2}$ & ----- & ----- & $\mathrm{mg} / \mathrm{dm}^{3}$ \\
\hline $0-20$ & 4.7 & 40 & 8 & 42 & 4.7 & 19 & 9 & 32 & 75 & 43 & - \\
\hline
\end{tabular}




\subsection{Planting, Treatment, and Cultivation}

Using randomized complete block design, four organic compost treatments were randomly assigned to four plots in each of the 5 blocks, totaling twenty plots with five plans. The blocks measured $17.9 \mathrm{~m}$ long and divided by $2.5 \mathrm{~m}$ rows. Five replicas of $B$. suaveolens were planted in each plot, which was separated by a living fence of a control plant to avoid potential leaching of nutrients from or to a neighboring parcel. B. suaveolens plants were spaced $2.0 \times 1.3 \mathrm{~m}$ from each other. A soil protective culture of Crotalaria juncea was installed in the center of the rows and around the experimental area both to fix nitrogen and, as observed later, to mitigate the damage to the studied culture caused by insects, as a trap crop (Gliessman, 2001).

Four treatments had no organic fertilizer added to the soil $\left(1^{\text {st }}\right.$ treatment, hereafter also called "control treatment"), and with 20,40 , and 60 ton/ha of organic compost, which was evenly incorporated into the soil near the root zone of the plants of their respective parcels $\left(2^{\text {nd }}, 3^{\text {rd }}\right.$, and $4^{\text {th }}$ treatment, respectively). All the compost added to the treatments was incorporated into the soil manually, close to the root zone of the plants with the help of a wooden stake. To measure the volume applied, fifteen-liter bucket was used. The organic compost was prepared at the Department of Horticulture (FCA/UNESP), and its composition is listed in Table 3. Ten days after organic compost incorporation, seedlings prepared as described in subsection 2.1 were transplanted to the field. Each parcel received five plants on 17 December 2016 (summer time in Brazil). The pits were dug with a hand excavator, the bottom of the seedling bags cut to expose the roots, and the seedings transplanted individually one by one. After positioning, a thin cover of straw was placed around each. The seedlings were watered immediately after transplant.

Table 2. Nutrient ratio of the compound (Campos, 2013)

\begin{tabular}{|c|c|c|c|c|c|c|c|c|c|c|}
\hline $\mathrm{pH}$ & $\mathrm{U} 65^{\circ} \mathrm{C}$ & M.O. & $\mathrm{C}$ & $\mathrm{C} / \mathrm{N}$ & $\mathrm{N}$ & $\mathrm{K}$ & $\mathrm{Ca}$ & $\mathrm{Mg}$ & $\mathrm{P}$ & $\mathrm{S}$ \\
\hline & \multicolumn{10}{|c|}{------------------ \% ----------------- } \\
\hline 7.7 & 13 & 34 & 19 & 11 & 1.8 & 0.6 & 1.8 & 0.4 & 1.4 & 0.3 \\
\hline $\mathrm{Na}$ & & $\mathrm{Cu}$ & & $\mathrm{Fe}$ & & $\mathrm{Mn}$ & \multicolumn{4}{|c|}{$\mathrm{Zn}$} \\
\hline ---- & & 63 & & $\begin{array}{r}--\mathrm{mg} / \\
10005\end{array}$ & dry & $\begin{array}{l}r---- \\
348\end{array}$ & \multicolumn{4}{|c|}{120} \\
\hline
\end{tabular}

The cultural was regularly irrigation and sick leaves removed. Inspections identified pests and diseases, and when a chewing insect was found, it was manually removed and taken outside the experimental area. Throughout the development of plants, spontaneous plants emerged that harnessed through selective supinations, maintaining a living plant cover in the soil with Bracchiaria decubens between the parcels to minimize erosion processes caused by the heavy summer rains.

\subsection{Harvest and Dry Mass Measurements}

Four months after planting in the field (at the beginning of autumn, which was when the rains ceased), the aerial parts of the plants were harvested. All plants were pruned at a height of $20 \mathrm{~cm}$ above ground level, using shears. The material was packed in plastic bags and identified with the numbers of treatments, blocks, and repetitions. The leaves and stems of the plants were separated and immediately weighted to obtain data of the fresh matter. Then they were dried in greenhouses at $40{ }^{\circ} \mathrm{C}$ and weighing again until constant weight was verified.

The data were analyzed by analysis of variance (ANOVA), followed by Tukey's multiple comparisons test, considering 5\% level of significance. For this, the software SISVAR (version 5.6) was used.

\subsection{Analysis of Alkaloids}

\subsubsection{Standard Solutions}

Appropriate amounts of atropine sulfate and scopolamine hydrobromide analytical standards (both purchased from SIGMA-ALDRICH, USA) were weighed and added in chromatographic grade methylene chloride (Merck, USA) to achieve a stock solution with concentration of $1.0 \mathrm{mg} / \mathrm{mL}$. Each stock solution was diluted to obtain a calibration curve built with concentrations of 50,100,150,200, and $250 \mathrm{mg} / \mathrm{L}$.

\subsubsection{Preparation of Brugmansia suaveolens Extracts}

First, dry leaves of five plants of a given treatment of each block were mixed and grounded. A potion of $10 \mathrm{mg}$ was separated and identified with the numbers of the block (1-5) and the treatment (1-4). Then, $10 \mathrm{mg}$ of each of the five blocks of a given treatment were put together in a vial thus totalizing $50 \mathrm{mg}$ of each treatment. An 
aliquot of $250 \mu \mathrm{L}$ of sodium borate buffer (100 MM and $\mathrm{pH} 9$ ) was added to the vial and the mixture was kept under constant agitation using a magnetic stirring bar, for $1 \mathrm{~h}$. Then $3 \mathrm{~mL}$ of dichloromethane was added, and the mixture agitated for $4 \mathrm{~h}$, at $25^{\circ} \mathrm{C}$. Finally, the obtained extract was diluted until $5.0 \mathrm{~mL}$ and filtered with a $45 \mu \mathrm{m}$ membrane filter. This procedure was repeated five times for each treatment.

\subsubsection{Quantification of Alkaloids Atropine and Scopolamine by GC-MS}

Analyses were performed without derivatization (Popl, Fähnrich \& Tatar, 2017) in a system comprise of a gas chromatograph coupled to a mass spectrometer with an electronic impact ionizing source type and a single quadrupole analyzer Clarus 680 and SQ8T, respectively, (PerkinElmer, Shelton, CT, USA). Separations were achieved using an Elite-5MS column $30 \mathrm{~m} \times 0.25 \mathrm{~mm} \times 0.25 \mu \mathrm{m}$ (PerkinElmer Shelton, CT, USA).

The alkaloids were quantified using the SIFI ${ }^{\mathrm{TM}}$ method (this is a method of individually monitoring of ions - SIR and full scan of the determined range of masses at the same time), from the analytical curves described in 2.6.1. An aliquot of $1 \mu \mathrm{L}$ of the standards and sample solutions (described in 2.6.1 and 2.6.2) was injected into the system. The following instrumental conditions were used: temperature of the injector was $250{ }^{\circ} \mathrm{C}$, with the oven program for: $60{ }^{\circ} \mathrm{C}(2 \mathrm{~min}), 20^{\circ} \mathrm{C} / \mathrm{min}$ until $280{ }^{\circ} \mathrm{C}, 280{ }^{\circ} \mathrm{C}(7 \mathrm{~min}$.). Helium was used as the carrier gas. Under these conditions atropine and scopolamine have retention times in 12.5 and $13.07 \mathrm{~min}$, respectively. Acquisition mode in SIFI method: full scan ( $\mathrm{m} / \mathrm{z}$ 50-500), SIR at 82, 94, 124, and $289 \mathrm{~m} / \mathrm{z}$ for atropine and 94, 108, 138, 1154, and $303 \mathrm{~m} / \mathrm{z}$ for scopolamine.

\section{Results and Discussion}

\subsection{Dry Matter Production of Different Treatments}

The dry matter productivity of leaves and stems of $B$. Suaveolens related to organic compost dosage are shown in Table 3.

Table 3. Average dry mass of leaves or stems per plant of B. suaveolens grown in Botucatu (São Paulo, Brazil) using different organic compost dosages

\begin{tabular}{lll}
\hline Organic fertilizer (ton/ha) & Leaf dry matter $(\mathrm{g})$ & Stem dry matter $(\mathrm{g})$ \\
\hline 0 (control) & $26.54(5.12) \mathrm{c}$ & $26.73(8.51) \mathrm{b}$ \\
20 & $38.10(9.6) \mathrm{cb}$ & $44.64(13.11) \mathrm{a}$ \\
40 & $43.3(9.05) \mathrm{ba}$ & $54.70(13.15) \mathrm{a}$ \\
60 & $55.41(12.85) \mathrm{a}$ & $58.60(17.62) \mathrm{a}$ \\
Coefficient of Variation (\%) & 40.05 & 46.37 \\
\hline
\end{tabular}

Note. Averages followed by distinct lowercase letters in a column indicate significant differences between levels of organic fertilization $(\mathrm{p}<0.05)$ by Tukey's test.

The dry matter production of leaves or stems per plant were very similar, with in the range of 26.5-58.6 $\mathrm{g}$ from 0 to 60 ton/ha (Table 3). Thus, if both plant parts were used as a raw material, productivity would be doubled. The increase in leaf dry matter was directly proportional to the organic compost dosage (Table 3 ). The average leaf dry matter per plant ranged from $26.54 \pm 5.12$ to $55.41 \pm 12.85 \mathrm{~g}$ from 0 to 60 ton/ha, which is clearly observed in Figure 1. The same trend was observed for stem dry matter (Table 3), which ranged from $26.73 \pm 8.51$ to $58.60 \pm 17.62 \mathrm{~g}$ from 0 to 60 ton/ha.

Analysis of Variance (ANOVA) with 95\% confidence level evidenced the advantages of applying a dosage of 40-60 ton/ha to obtain the maximum productivity of leaves (Table 3). For stem production, any treatment with organic compost led to higher efficiencies compared to the control, when no organic compost was supplied to the plants (Table 3). However, no evident statistical difference was observed among treatments. Overall, a treatment with $60 \mathrm{ton} / \mathrm{h}$ of the organic compost employed here should be preferred over the other treatments or control to achieve the maximum productivity of total dry mater (leaves and stems together).

These findings corroborate others reported in the literature. For example, Garcia et al. (2017) found that the increasing dosages of organic fertilizer ( 0 to 50 ton/ha) increased the diameter, dry matter, and fresh matter of plants Baccharis trimera (Less). The productivity of dry leaves in essential oil increased $0.14 \%$ from control to the maximum dosage tested. On the other hand, Ferreira (2003) found that organic fertilization with bovine manure at $0-60$ ton/ha increasingly influenced the development of morphological characteristics of Catharanthus roseus plants, such as their height, leaf dry matter and stem diameter. Chaves et al. (2002) observed that doses of 
chicken manure statistically influenced the production of leaves, stems, buds, and total yields of Ocimum gratissimum L. Sreevalli, Kulkarni, Baskaran, and Chandrashekara (2003), concluded that N fertilization significantly increased the content of alkaloids both in leaves and roots of all Catharanthus roseus genotypes. These examples provide evidence that nitrogen is probably related to the alkaloids production.



Figure 1. Linear curve of dry matter production in leaves and stems

\subsection{Alkaloids Analysis}

First, the tropane alkaloids scopolamine and atropine were identified in the B. suaveolens extracts made from dry leaves prepared from each treatment. The GC-MS chromatogram is shown in Figure 2.

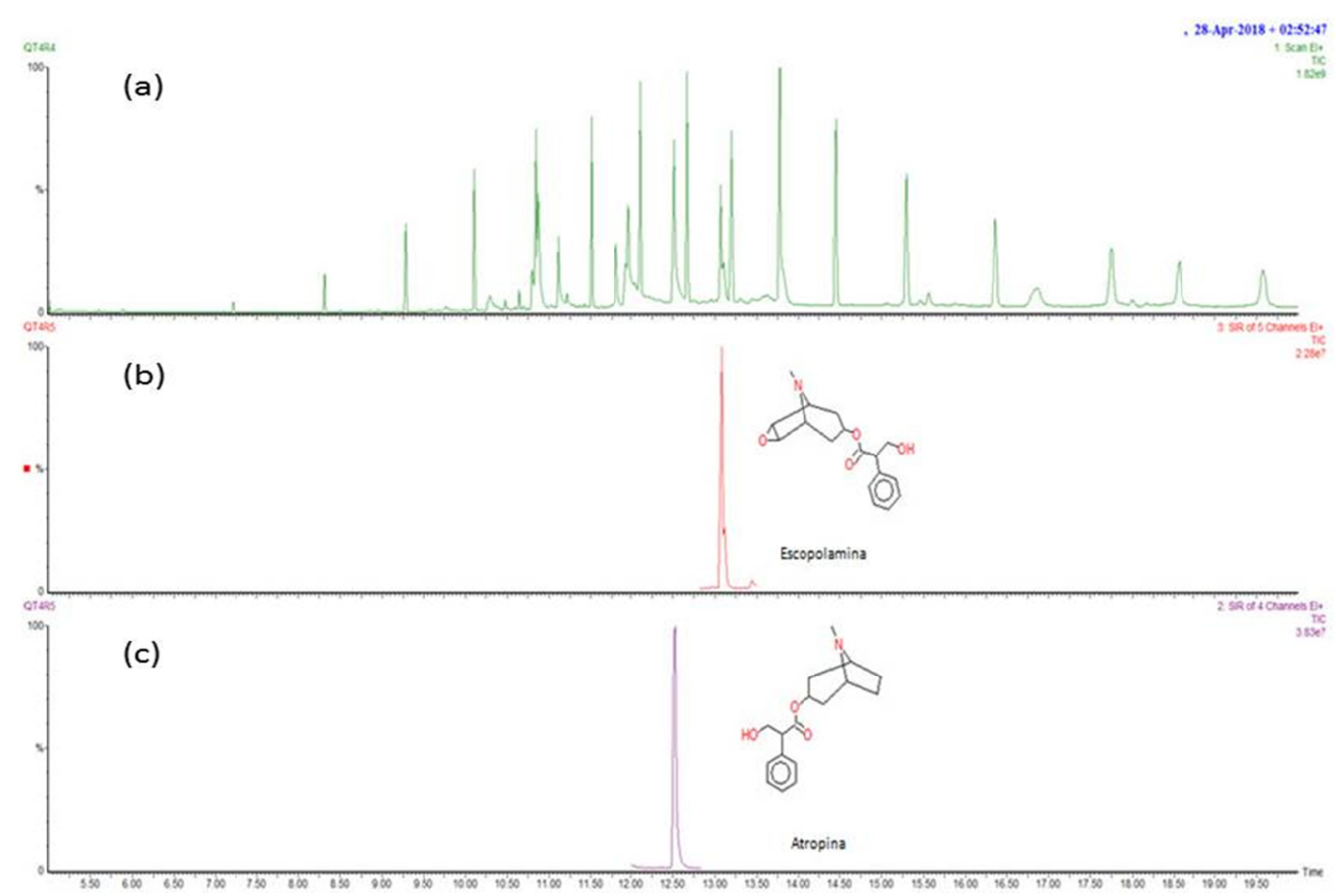

Figure 2. GC-MS full scan chromatogram of a representative extract of leaves of B. suaveolens (a) and selected ion for scolopamine (b) and atropine (c)

Then, quantitative analyses were performed for five replicates of each treatment, and atropine and scopolamine contents were calculated from calibration curves obtained with pure standard solutions (subsection 2.6). Results were submitted to ANOVA and are presented in Table 4. 
Table 4. Atropine and scopolamine contents in leaves of B. suaveolens grown in Botucatu (São Paulo, Brazil) under different organic compost dosages

\begin{tabular}{lll}
\hline Organic fertilizer (ton/ha) & Atropine $(\mathrm{mg} / \mathrm{g})$ & Scopolamine $(\mathrm{mg} / \mathrm{g})$ \\
\hline 0 (control) & $0.79(0.03) \mathrm{b}$ & $0.72(0.05) \mathrm{ab}$ \\
20 & $0.90(0.05) \mathrm{ab}$ & $0.79(0.04) \mathrm{ab}$ \\
40 & $0.85(0.07) \mathrm{ab}$ & $0.70(0.07) \mathrm{b}$ \\
60 & $0.96(0.11) \mathrm{a}$ & $0.86(0.13) \mathrm{a}$ \\
coefficient of variation $(\%)$ & 8.39 & 11.02 \\
\hline
\end{tabular}

Note. Average value followed by distinct lowercase letters in a column indicate significant differences between levels of organic fertilization $(\mathrm{p}<0.05)$ by Tukey's test.

The average contents of both alkaloids plotted against the dosage of organic compost follow the trend of increasing atropine and scopolamine contents with increasing organic compost supply (Figure 3).

The quantitative analyses indicated that a higher content of atropine $(0.96 \pm 0.11 \mathrm{mg} / \mathrm{g})$ was achieved for the extract obtained from leaves from plants treated with $60 \mathrm{t} / \mathrm{ha}$ of organic compost. Statistically, the alkaloid atropine presented homoscedasticity and normality. The analysis of variance (ANOVA) with Tukey's test, CV (\%) $=8.39 \%$ demonstrated a difference between this treatment and control (without fertilization, $0.79 \pm 0.03 \mathrm{mg} / \mathrm{g}$ ) (Table 4).

The higher content $(0.86 \pm 0.13 \mathrm{mg} / \mathrm{g})$ of scopolamine was also achieved for treatment with $60 \mathrm{t} / \mathrm{ha}$ of organic compost. The statistical analysis of scopolamine also had homoscedasticity and normality. The ANOVA pointed Tukey's test, $\mathrm{CV}(\%)=11.02 \%$, found a difference between treatment 40 and 60 ton/ha. These findings corroborate those from other authors. In a series of experiments performed with Brugmansia candida in tissue culture, Pitta-Alvarez, Spollansky and Giulietti (2000) observed higher productivity in the biosynthesis of scopolamine when providing silver nitrate to the plants $\left(\mathrm{AgNO}_{3}\right)$, concluding that higher contents of alkaloids in $B$. candida are associated with higher nitrogen supply. Similarly, Becker et al. (2000) observed gradual increase in the concentration of alkaloids in the dry matter of Phyllanthus niruri L., aerial parts as the doses of supplied nitrogen increased in the presence of calcium carbonate.

According to Gobbo-Neto and Lopes (2007), the production of compounds containing nitrogen by plants has distinct behavior from other types of secondary metabolites production from such organisms. Usually plants growing in soils with poor nutrients produce higher amounts of secondary metabolites other than the nitrogen ones. Instead, the production of nitrogen secondary metabolites, such as alkaloids, is generally increased with the highest availability of nitrogen in the soil. Conversely, the deficiency of nitrogen rich nutrients in the soil should reduce the synthesis of the nitrogen compound such as alkaloids (Gobbo-Neto \& Lopes, 2007).

The contents of atropine $(0.79-0.96 \mathrm{mg} / \mathrm{g})$ and scopolamine $(0.72-0.86 \mathrm{mg} / \mathrm{g})$ found in this work were close to those reported in literature for the same species or for other species of the same genus. According to Rätsch (1997), these alkaloids are present in aerial parts of B. suaveolens in a range from 0.9-1.6 mg/g in dry weight. Evans and Lampard (1972) reported total alkaloid contents of 2.9-3.5 mg/g calculated as scopolamine in dried calyx and corolla of Datura suaveolens, depending on the age of the plant. B. sanguinea, which is cultivated commercially in Ecuador, has also proved to be an interesting source of several tropane alkaloids with yields about $0.8 \mathrm{mg} / \mathrm{g}$ of scopolamine (Evans, 2009).

Jakabová et al. (2012) found atropine and scopolamine contents in leaves of Datura innoxia Mill ranging from 0.02-0.06 and 0.94-4.53 mg/g, respectively. For Datura metel L., these ranges were 0.07-1.43 and 0.13-0.28 $\mathrm{mg} / \mathrm{g}$, respectively, whereas they were $0.43-4.71$ and $0.13-1.79$ for $D$. stramonium var. tatula L., respectively.

The atropine $(0.79-0.96 \mathrm{mg} / \mathrm{g})$ and scopolamine $(0.72-0.86 \mathrm{mg} / \mathrm{g})$ contents found in this work were almost $1: 1$ (Table 5). Evans (2009) mentioned that the relative ratios of scopolamine and hyoscyamine in a species of genus Datura not only vary with age of the plant, but also are susceptible to the factors mentioned above, as well as chemical sprays, hormones, debudding, and chemical races. 


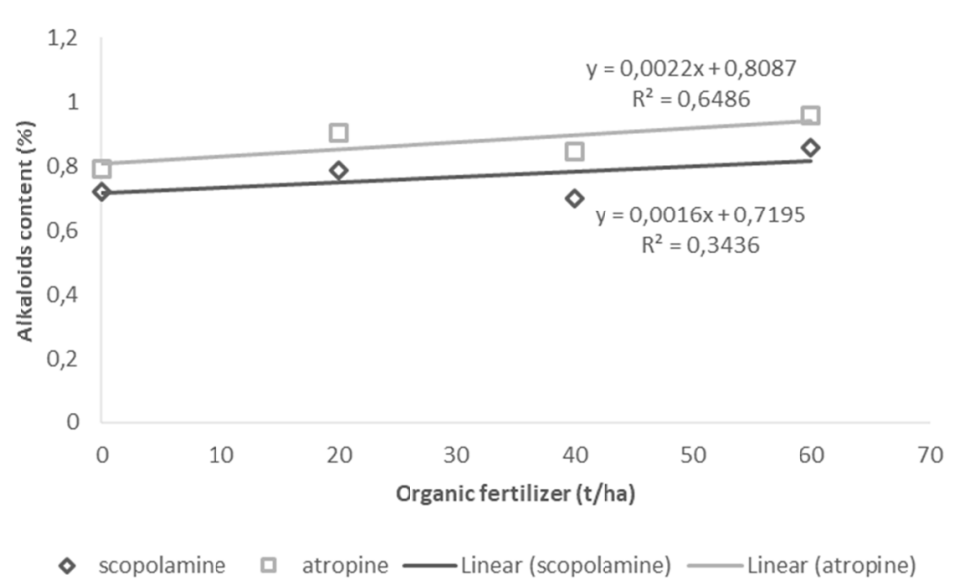

Figure 3. Atropine and scopolamine contents found in Brugmansia suaveolens grown in different dosages of organic compost

\subsection{General Observations During Seedling and Cropping}

For a brief period before harvesting, the cloudy and rainy climate brought a rapid response from the plants with the growth of new green branches. Lorenzi and Souza (2008) mentioned that the Brugmansia suaveolens is cultivated in full sun, usually as an isolated plant. However, Rätsch (1997) emphasizes that it is a plant that grows to half shade, with this fact confirmed in the experimental cultivation.

After a few days, some pests arrived in the field and attacked some plots. The presence of grasshoppers and grass ants were detected. Then a protective culture was planted for dispersion and protection, which decreased the incidence of insect attacks at the experimental site.

According to Verma and Shukla (2015), water regime (wet or dry soil), general climatic conditions, including length of day, season of harvesting, and light intensity, are among the factors that influence the production of alkaloids and other classes of secondary metabolites and insect attack.

\section{Conclusions}

Overall, this work revealed that the organic fertilizer treatment at maximum level tested in this work $(60$ ton/ha) is preferred over the other treatments. The production of the aerial parts of B. suaveolens plants increased as the amount of organic fertilizer provided to the plants increased. The same behavior was observed when the contents of the active tropane alkaloids scopolamine and atropine were monitored. Future works should investigate whether the production of aerial parts of B. suaveolens and the contents of scopolamine and atropine in them could be enhanced by feeding plants with dosages higher than 60 ton/ha. This work also evidenced that $B$. suaveolens is a potential source of tropane alkaloids for the community of Botucatu city, which is a leading city in Brazil in the cultivation of food products under organic, biodynamic, and agroecology premises.

\section{References}

Becker, L., Neto, A. E. F., Pinto, J. E. B. P., Cardoso, M. G., Santos, C. D., Barbosa, J. M., ... Santiago, E. J. A. (2000). Crescimento e produção de alcaloides totais de quebra-pedra em função da calagem e da adubação nitrogenada. Horticultura Brasileira, 18(2), 100-104. https://doi.org/10.1590/S0102-05362000000200004

Campos, M. G. (2015). Efeito da adubação orgânica na produção de fitomassa e nos compostos bioativos de Passiflora incarnata L. (Master's thesis, UNESP, San Paolo, Brazil). Retrieved from http://www.pg.fca. unesp.br/Teses/PDFs/Arq1254.pdf

Cardillo, A. B., Otálvaro, A. M., Busto, V. D., Talou, J. R., Velásquez, M. E., \& Giulietti, A. M. (2010). Scopolamine, anisodamine and hyoscyamine production by Brugmansia candida hairy root cultures in bioreactors. Process Biochemistry, 45, 1577-1581. https://doi.org/10.1016/j.procbio.2010.06.002

Chaves, F. C. M., Ming, L. C., Ehlert, P. A. D., Fernandes, D. M., Marques, M. O. M., \& Meireles, M. A. A. (2002). Influence of organic fertilisation on leaves and essential oil production of Ocimum gratissimum L. Acta Horticulturae, 576, 273-275. https://doi.org/10.17660/ActaHortic.2002.576.40 
Coherent Market Insights Analysis. (2018). Globe News Wire. Retrieved July 18, 2018, from https:/globenewswire.com/news-release/2018/07/18/1538971/0/en/Global-Scopolamine-Market-to-Surpass -US-563-3-Million-by-2026-Coherent-Market-Insights.html

Evans, W. C. (2009). Pharmacognosy (16th ed.). International Edition: Saunders Elsevier.

Evans, W. C., \& Lampard, J. F. (1972). Alkaloids of Datura suaveolens. Phytochemistry, 11, 3293-3298. https://doi.org/10.1016/S0031-9422(00)86392-X

Ferreira, M. M. (2003). Avaliação das características de crescimento e desenvolvimento da vinca (Catharanthus roseus) em relação a adubação e época de colheita (p. 63, Dissertação (Master's thesis), Instituto de Fitotecnia, Universidade Federal de Lavras, Lavras, MG).

Garcia, D., Silva, P. S. S., Furlan, M. R., Isobe, M. T. C., Marques, M. O. M., \& Ming, L. C. (2017). Effect of organic fertilizer on the plant growth, essential oil production and chemical substances of "Carqueja" over two harvest moments. Journal of Agricultural Science and Technology, B 7, 114-124.

Gliessman, S. R. (2001). Agroecologia: processos ecológicos em agricultura sustentável. Rio Grande do Sul: Editora da Universidade Federal do Rio Grande do Sul.

Gobbo-Neto, L., \& Lopes, N. P. (2007). Plantas medicinais: Fatores de influência no conteúdo de metabólitos secundários. Ribeirão Preto: Quim. Nova.

Jakabová, S., Vincze, L., Farkas, A., Kilár, F., Boros, B., \& Felinger, A. (2012). Determination of tropane alkaloids atropine and scopolamine by liquid chromatography-mass spectometry in plant organs of Datura species. Journal of Chromatography A, 1232, 295-301. https://doi.org/10.1016/j.chroma.2012.02.036

Lorenzi, H., \& Souza, H. M. (2008). Plantas ornamentais do Brasil: Arbustivas, herbáceas e trepadeiras. Nova Odessa, SP: Instituto Plantarum. https://doi.org/10.1590/S0034-72992008000300002

Lorenzi, H., Matos, F. J. A., Santos, L. F. L., Matos, M. E. O., Silva, M. G. V., \& Sousa, M. P. (2011). Plantas tóxicas: estudo de fitotoxicologia química de plantas brasileiras. São Paulo: Instituto Plantarum. https://doi.org/10.1177/1099800406293984

Parker, A. G., Peraza, G. G., Sena, J., Silva, E. S., Soares, M. C. F., Vaz, M. R. C., ... Muccillo-Baisch, A. L. (2007). Antinociceptive effects of the aqueous extract of Brugmansia suaveolens flowers in mice. Biological Research for Nursing, 8(3), 234-239. https://doi.org/10.1177/1099800406293984

Pitta-Alvarez, S. I., Spollansky, T. C., \& Giulietti, A. M. (2000). The influence of different biotic and abiotic elicitors on the production and profile of tropane alkaloids in hairy root cultures of Brugmansia candida. Enzyme and Microbial Technology, 26, 252-258. https://doi.org/10.1016/S0141-0229(99)00137-4

Popl, M., Fähnrich, J., \& Tatar, V. (2017). Chromatographic Analysis of Alkaloids. Boca Raton: Routledge.

Qiang, W., Xia, K., Zhang, Q., Zeng, J., Huang, Y., Yang, C., ... Liao, Z. (2016). Functional characterization of a tropine-forming reductase gene from Brugmansia arborea, a woody plant species producing tropane alkaloids. Phytochemistry, 127, 12-22. https://doi.org/10.1016/j.phytochem.2016.03.008

Rätsch, C. (1997). The encyclopedia of psychoactive plants: Ethnopharmacology and its applications. Switzerland: Park Street Press Rochester.

Revilla, J. (2002). Plantas úteis de Bacia Amazônica Manaus: INPA-SEBRAE.

Santos, D. G. P. O. (2016). Produção de biomassa e teor de cumarina em folhas de guaco (Mikania laevigata Sch. Bip. ex Baker) em diferentes idades da planta (Master's thesis, UNESP, San Paulo, Brazil). Retrieved from https://repositorio.unesp.br/bitstream/handle/11449/138871/santos_dgpo_me_bot.pdf?sequence=3

Schultes, R. E., \& Hofmann, A. (1983). Botanica e chimica degli allucinogeni. Italy: Cesco Ciapanna Editore S.P.A.

Sreevalli, Y., Kulkarni, R. N., Baskaran, K., \& Chandrashekara, R. S. (2003). Increasing the content of leaf and root alkaloids of high alkaloid content mutants of periwinkle through nitrogen fertilization. Industrial Crops and Products, 19, 191-195. https://doi.org/10.1016/j.indcrop.2003.09.005

Verma, N., \& Shukla, S. (2015). Impact of various factors responsible for fluctuation in plant secondary metabolities. Journal of Applied Research on Medicinal and Aromatic Plants, 2, 105-113. https://doi.org/ 10.1016/j.jarmap.2015.09.002

World Health Organization. (2003). Guidelines on good agricultural and collection practices (GACP) for medicinal plants (p. 72). Geneva. 


\section{Copyrights}

Copyright for this article is retained by the author(s), with first publication rights granted to the journal.

This is an open-access article distributed under the terms and conditions of the Creative Commons Attribution license (http://creativecommons.org/licenses/by/4.0/). 